\title{
ERRATUM
}

\section{Arming a replicating adenovirus with osteoprotegerin reduces the tumor burden in a murine model of osteolytic bone metastases of breast cancer}

JJ Cody, AA Rivera, GR Lyons, SW Yang, M Wang, DB Sarver, D Wang, KS Selander, H-C Kuo, S Meleth, X Feng, GP Siegal and JT Douglas

\section{CORRIGENDUM}

\section{A modified hTERT promoter-directed oncolytic adenovirus replication with concurrent inhibition of TGF $\beta$ signaling for breast cancer therapy}

Z Hu, JS Robbins, A Pister, MB Zafar, Z-W Zhang, J Gupta, KJ Lee, K Newman, C-O Yun, T Guise and P Seth 